University of Nebraska - Lincoln

DigitalCommons@University of Nebraska - Lincoln

Faculty Publications, Department of History

History, Department of

$9-24-1991$

\title{
Church Discipline and Moral Reformation in the Thought of Martin Bucer
}

Amy Nelson Burnett

University of Nebraska - Lincoln, aburnett1@unl.edu

Follow this and additional works at: https://digitalcommons.unl.edu/historyfacpub

Part of the History Commons

Burnett, Amy Nelson, "Church Discipline and Moral Reformation in the Thought of Martin Bucer" (1991). Faculty Publications, Department of History. 21.

https://digitalcommons.unl.edu/historyfacpub/21

This Article is brought to you for free and open access by the History, Department of at DigitalCommons@University of Nebraska - Lincoln. It has been accepted for inclusion in Faculty Publications, Department of History by an authorized administrator of DigitalCommons@University of Nebraska - Lincoln. 


\title{
Church Discipline and Moral Reformation in the Thought of Martin Bucer
}

\author{
Amy Nelson Burnett \\ University of Nebraska-Lincoln
}

Martin Bucer understood church discipline in a broad sense to include four elements: the religious instruction of children and adults through catechization and private confession or individual meetings between pastor and parishioner; a public profession of faith and obedience to the church and its ministers, ideally made when a child was confirmed; the practice of mutual fraternal admonition combined with the oversight of morals by pastors and lay elders; and the imposition of public penance and, if necessary, excommunication, in cases of grave public sin. Church discipline in this broad sense was intended to promote the individual Christian's progress in piety, to strengthen the church community, and to result in a Christian transformation of society.

"DR. BUCER INCESSANTLY CLAMORS that we repent, that we give up the depraved customs of hypocritical religion, that we correct the abuses of feast days, that we more frequently give and hear sermons, that we apply some kind of discipline. He impresses on us many things of this kind ad nauseum."1 So one student at Cambridge wrote in 1550, describing the preaching and teaching of the new professor of theology, Martin Bucer.

After twenty-five years as de facto head of the evangelical church in Strasbourg, Bucer had been forced to leave the city in 1549 by the introduction of the Augsburg Interim. He had come to England at the invitation of Archbishop Thomas Cranmer and become Regius Professor of theology at Cambridge. Through his preaching and teaching Bucer hoped to help the English church avoid the punishment he believed was inflicted upon Germany by God because of its neglect of church discipline. Bucer's insistence on the need for church discipline was a hallmark of the later years of his ministry, but his concern for what he regarded as proper Christian behavior stretched back over his long career as a Protestant minister.

Bucer was not alone in his concern for Christian conduct. The reformers' break with the Catholic church had entailed not only a change in doctrine for their followers but involved a transformation of religious practice and social behavior as well. For most of the laity, the changes in

1Thomas Horton to Francisco Dryander, May 15, 1550, Thesaurus Epistolicus Reformatorum Alsaticorum (TB) XX, p. 180, in the Bibliothèque nationale et universitaire of Strasbourg; the original Latin quote is given in A.E. Harvey, Martin Bucer in England (Marburg: Bauer, 1906), 48-49. 


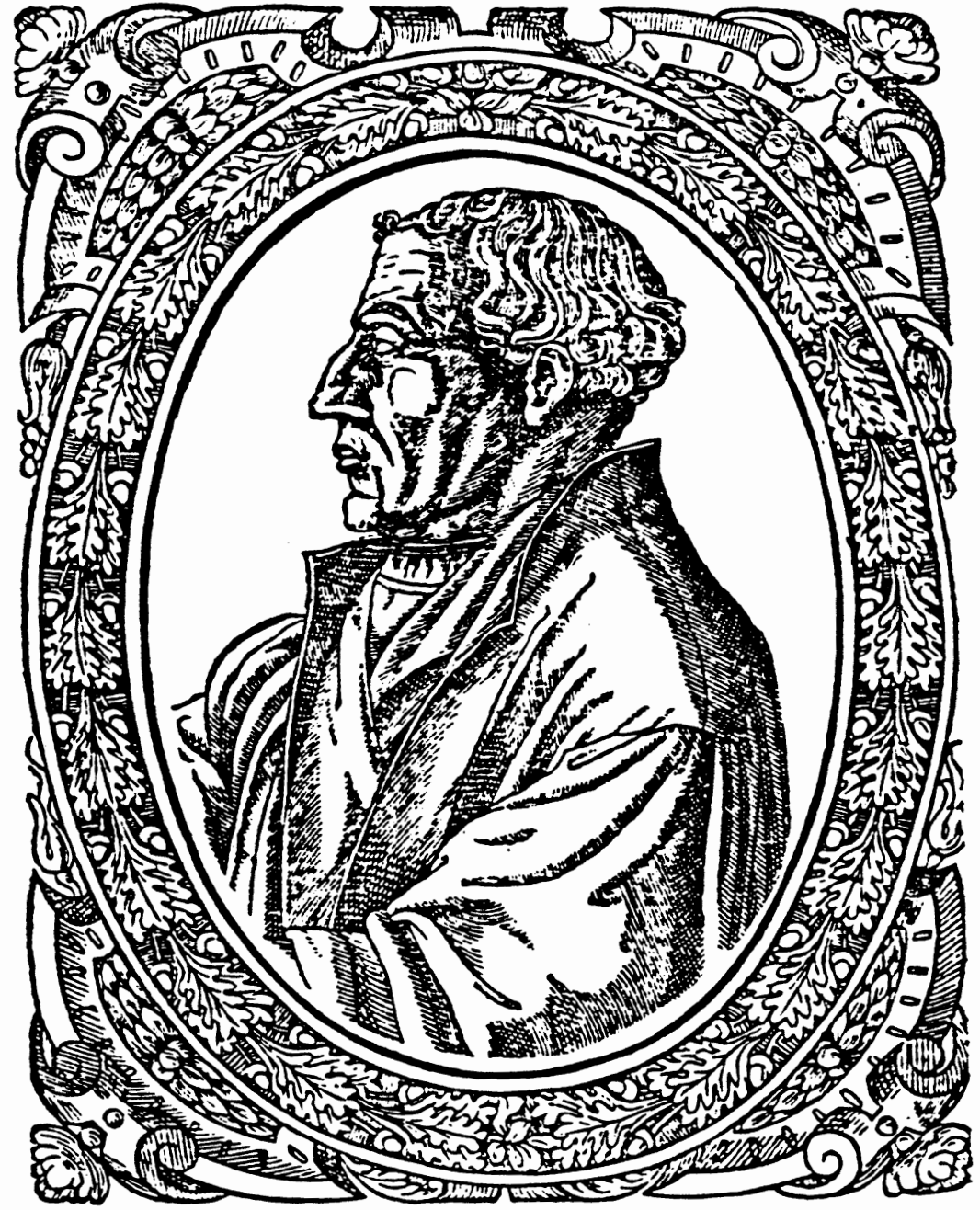

MARTIN BUCER. 
way of life were much more understandable than were the technicalities of the manner-if any-of Christ's presence in the Eucharist or the precise relationship between faith and works. Thus when in late 1536 the papal nuncio Peter van der Vorst compiled a list of the most important of the religious issues disputed in Germany, he focused on those controversies which involved religious practice, such as clerical celibacy, the administration of the Eucharist to the laity in one form only, and the requirement of the yearly confession of all sins to a priest, rather than on the doctrinal differences which later theologians have cited as the unbridgeable chasm between evangelicals and Catholics. ${ }^{2}$

While many of the laity may have seen the Reformation as an opportunity to throw off the regulations and requirements of the medieval church, the reformers themselves, especially those who had been influenced by the biblical humanism of Erasmus, were concerned with forming a new Christian society. Their sermons contained both a negative message which rejected what they saw as the abuses and superstitions of the Catholic church and a positive message which outlined the duties and responsibilities of the evangelical laity towards God and neighbor.

This emphasis on the building of a Christian society is especially evident in the writings of Martin Bucer. His first book, published shortly after his arrival in Strasbourg in 1523, described how a person who has been redeemed through faith in Christ lives no longer for himself but for the sake of service to his neighbor. ${ }^{3}$ Bucer spent much of his ministry trying to create ecclesiastical institutions which would encourage this kind of active Christian faith in the evangelical laity. His goal was to transform the church into a God-fearing community which demonstrated its faith through concern for the spiritual and physical well-being of its members. The means for this transformation was the reintroduction of Christian discipline.

For Bucer, this meant more than simply punishing those who had sinned. In his mature works, his understanding of discipline had four elements: religious instruction for both children and adults; a public confession of faith and obedience, especially as part of a confirmation ceremony; fraternal admonition combined with the oversight of morals by pastors and lay elders; and in cases of grave sin, the imposition of public penance and, if necessary, excommunication.

Religious instruction was the foundation of the system. It was to be carried out both publicly, through catechetical instruction, and privately,

${ }^{2}$ Hubert Jedin, A History of the Council of Trent, vol. 1: The Struggle for the Council, trans. Dom Ernest Graf, O.S.B. (St. Louis: Herder, 1957), 408, citing Consilium Tridentinum: Diarorum, actorum, epistolarum, tractatuum nova collectio, ed. GörresGesellschaft (Freiburg, 1901-), 4:62.

${ }^{3} \mathrm{Cf}$. the title of the work, Das ym selbs niemant, sonder anderen leben soll, und wie der mensch dahyn kummen mög, printed in Martin Bucer, Opera Omnia, Series 1: Deutsche Schriften (Gütersloh: Gerd Mohn, 1960-), vol. 1 (hereafter referred to as DS). 
through private confession. Regular catechetical instruction had been established relatively early in Strasbourg. By 1526, three years before Luther published his catechisms, there were weekly catechism classes for children in the city's churches, and every three months special catechetical services were held which were intended especially for servants. ${ }^{4}$

Bucer himself published three different catechisms, and he repeatedly urged the Strasbourg Senate to require that children and servants attend both weekly and quarterly catechism instruction. As the pastors noted in a memorandum submitted to the Senate in 1536, all properly ordered churches had some form of private instruction, as confession had been under the papacy. They could not require confession according to the Gospel, but in not establishing a substitute for it they merited God's punishment. Young people learned to avoid the papal yoke, but they were not offered the yoke of Christ in its place. The pastors protested against the view that the people were to be left without any regulation whatsoever, claiming that "the Gospel does not require that we destroy the pope's ordinances and not replace them with Christian ones." The pastors asked that the Senate issue a mandate giving them the authority to instruct children privately in the basics of the catechism - the Ten Commandments, the Creed, the Lord's Prayer, and the understanding of the sacraments. When the children had learned this, they could be admitted to the Lord's Supper. ${ }^{5}$

The senators were not so convinced of the need to strengthen the pastors' authority and make catechism attendance mandatory. They acknowledged that it certainly was desirable that everyone attended the quarterly catechisms along with wife, children and servants, but they were convinced that such attendance could not be compelled. The pastors were to admonish parishioners from the pulpit to attend the catechism and to send their children to church and the weekly catechism services, and the senators were also to encourage their fellow guildsmen in the same, but there would be no mandate requiring attendance. ${ }^{6}$ This remained the attitude of the Senate, despite the clergy's frequent complaints about "the untamed, rebellious and poorly-taught children" of Strasbourg "who would accept admonition, teaching or reproof from no one."7

During the early years of the Reformation the Strasbourg pastors rejected auricular confession as required by the Catholic church, but by the 1530s they were acknowledging the usefulness of private confession for

${ }^{4}$ August Ernst and Johann Adam, Katechetische Geschichte des Elsasses bis zur Revolution (Strasbourg: F. Bull, 1897), 115-16.

${ }^{5}$ Archives du Chapitre de Saint-Thomas (AST) 84, no. 30, fol. 100r, Archives Municipales of Strasbourg.

${ }^{6}$ AST 84 , no. 31, fol. $105 \mathrm{r}-108 \mathrm{v}$.

7Bucer's characterization in Von der kirchen mengel vnnd fähl, DS-17, p. 174. 
their church. The value of private confession was one of the issues on which Lutherans and Zwinglians differed. Although the Lutherans condemned the mandatory confession of all mortal sins, they required those who wished to receive the sacrament of the Lord's Supper to present themselves to their pastor beforehand, to be examined concerning life and morals and to confess and be absolved of any sins which burdened the conscience. Luther and his followers valued private absolution highly, as a means of reassuring troubled consciences of God's forgiveness. In the words of the Augsburg Confession, the Lutherans taught that the power of the keys, exercised in private absolution, is "comforting and necessary ... for terrified consciences . . . (and) that God requires us to believe this absolution as much as if we heard God's voice from heaven."

Zwingli was highly critical of Luther's position, accusing him of not properly understanding the power of the keys. He argued that a person's sins were forgiven as soon as he believed that God had forgiven them and was confident in that belief. If one did not have this confident faith, his sins would not be forgiven even though he were to confess to a priest a thousand times. ${ }^{9}$ The $Z$ winglians also rejected the pre-communion examination as "papistic."

Many reform-minded humanists held yet another view of private confession and absolution. While in general accepting the importance of priestly absolution, they questioned the necessity of confessing all sins to a priest and emphasized instead the usefulness of confession for providing instruction and counsel. This is the position advocated by the Basel reformer Johannes Oecolampadius in 1521, before his break with the Catholic church. In his book on the Paradox that Christian Confession is not Burdensome he condemned the psychotyranni who made confession onerous by demanding confession of all sins, but he taught that individuals should confess their sins to a priest or Christian brother for the sake of counsel. ${ }^{10}$ Beatus Rhenanus endorsed this position in his edition of Tertullian, also published in 1521, saying that Oecolampadius' book was a help to all who had been caught by superstitious traditions about confession. ${ }^{11}$ Erasmus expressed his own views on confession in his Exhomologesis, published in 1524. Sidestepping controversial issues such as the divine institution of auricular confession and the significance of priestly absolution, Erasmus chose to concentrate instead on the usefulness of confession to convict of $\sin$

${ }^{8}$ The Augsburg Confession, Art. XXV, in Theodore G. Tappert, trans. and ed., The Book of Concord (Philadelphia: Muhlenberg, 1959), 62.

${ }^{9}$ Schlußreden, in vol. 2 of Corpus Reformatorum, Huldrich Zwinglis sämtliche Werke, ed. E. Egli, et al. (Berlin/Leipzig/Zürich, 1905-; hereafter abbreviated as Z), 393-405. 1521).

${ }^{10} \mathrm{Quod}$ non sit onerosa Christianis confessio, paradoxon (Augsburg: Sigismund Grimm,

${ }^{11 E r n s t ~ S t a e h e l i n, ~ e d ., ~ B r i e f e ~ u n d ~ A k t e n ~ z u m ~ L e b e n ~ O e k o l a m p a d s, ~ z u m ~ v i e r h u n d e r t j a ̈ h r i g e n ~}$ Jubiläum der Basler Reformation, vol. 1, Quellen und Forschungen zur Reformationsgeschichte 10 (Leipzig: M. Heinsius, 1927), 367 n. 4. 
and promote love for God. He emphasized that priests ought not to undertake to hear confessions unless they were suitable in "doctrine, rectitude of soul, wisdom and especially piety."12

During the early years of his ministry at Strasbourg Bucer shared Zwingli's view that private absolution was meaningless. Nevertheless, like many humanists he valued the pedagogical importance of private confession and saw the private meeting between pastor and parishioner as a time for individual instruction and counsel. Given his rejection of private absolution, the moral character of the one to whom the penitent confessed was paramount. In his 1529 commentary on the Psalms, Bucer described the characteristics of a good confessor: he had to know what should be condemned, be kind to the one confessing and bear his burdens, reveal ardent love in all things, and help the one confessing through prayer, instruction, admonition, and consolation.

Bucer contrasted this description of a good confessor with the faults of an unworthy confessor, implying that confession made to the latter was completely worthless:

How can a person who is untrained in piety inflame others with it? If he overflows with every type of vice, by what method will he purge you of it? If he is wholly lacking knowledge and judgment, what will he teach you of them? If he never perceives the dejection of his own conscience, how will he encourage yours? In summary, how can anyone be the supporter or author of your amendment of life who is totally enslaved to his sins and never thinks of recoiling from them ${ }^{13}$

The moral character of the one to whom confession is made remained a constant concern in Bucer's later writings. During the religious colloquies with Catholic theologians in 1539-41 and the negotiations on the draft of the Augsburg Interim in 1548, Bucer continued to stress the need for pious and experienced confessors. ${ }^{14}$

After the Diet of Augsburg in 1530, Bucer became an indefatigable champion of concord between Lutherans and Zwinglians on the issue of the Lord's Supper. He spent several years devising various formulas describing the manner of Christ's presence in the sacrament, and through letters and personal visits to other theologians he attempted to persuade them that the difference between the two positions was more a matter of words than of substance. His efforts bore fruit in the Wittenberg Concord of 1536, in

${ }^{12}$ Desiderii Erasmii Roterodami Opera Omnia, ed. J. Clericus (Leiden, 1703; repr. London: Gregg, 1962), vol. 5, cols. 145-70; citation at col. 156.

${ }^{13}$ Sacrorvm Psalmorvm libri quinque ... (Strasbourg: Georgius Vlricherus Andlanus, (1532), 132B-D.

${ }^{14}$ In the negotiations concerning the Regensburg Book at Worms, Bucer saw as grounds for optimism the fact that the Catholics believed that only "older, proven men should be appointed" to hear confessions, Max Lenz, ed., Briefwechsel Landgraf Philipp's des Großmüthigen von Hessen mit Bucer, vol. 1, Publikationen aus den königlichen preussischen Staatsarchiven 5 (Leipzig: Hirzel, 1880), no. 106, pp. 288-89; cf. DS-17, p. 371. 
which the Lutherans recognized as orthodox the doctrine of the sacrament taught in the cities of southern Germany.

Bucer's growing appreciation of the Lutheran position on the Lord's Supper which resulted in the Wittenberg Concord led to a more favorable evaluation of private confession and absolution as well. The secret confession which he had written off as a human precept in the first edition of his commentary on the Gospels, published in 1527, was recommended in the second edition of the commentary, published in 1530: "Men should be taught that it is indeed Christian sometimes to confess their sins to men." He no longer asserted, as in the first edition, that the Lutheran view of absolution was unscriptural but instead gave a sort of apology: "I scarcely think that they feel that what they call private absolution has any ability of itself to soothe consciences, but rather that when brothers meet together and console one another, the Spirit of Christ, who renders efficacious the Gospel so heard in private, is not absent." 15 At the end of his ministry in Strasbourg Bucer echoed the words of the Augsburg Confession, stating that sinners who received absolution from the minister could have as much confidence in the forgiveness of their sins as if they had heard the voice of God from heaven. ${ }^{16}$ Nevertheless, in his discussions of private confession Bucer's chief emphasis remained its usefulness as a means for individual instruction, admonition and counsel.

Over the course of the 1530s Bucer also became a more outspoken advocate of the pre-communion examination. In a book published in 1534 he defended the Lutherans' use of such an examination against Anabaptist criticism. This position brought him into conflict with his Zwinglian friends, Thomas and Margareta Blarer, the brother and sister of the Constance reformer Ambrosius Blarer. Bucer complained in a letter to Ambrosius that his sister had accused him of being "out of his mind" because he had written that the less educated should be examined by the parish pastor before they were allowed to receive the Lord's Supper. ${ }^{17}$ Writing directly to Margareta and Thomas, Bucer stressed the need for such private catechization, "not compelled or extorted by a fear of excommunication but brought about by holy promptings," a practice which neither of the Blarers could condemn. He asserted that he opposed papal confession, in which those who had not confessed their secret sins were kept from the Lord's Table, but that he did not consider it "papistic" for a pastor to demand that the uneducated come to him before receiving communion in order to be instructed in its meaning, to confess both their

\footnotetext{
${ }^{15}$ Enarrationes perpetvae in sacra quatvor evangelia, recognitae nuper $\&$ locis compluribus auctae ... (Strasbourg: Georgivs Vlrichervs Andlanvs, 1530), 23A-B.

${ }^{16}$ Von der kirchen mengel vnnd fähl, DS-17, p. 176.

${ }^{17}$ Traugott Schieß, ed., Briefwechsel der Brüder Ambrosius und Thomas Blaurer 1509-1548, vol. 1 (Freiburg i.Br.: Fehsenfeld, 1908), no. 616, p. 724.
} 
faith and their sins, and to receive forgiveness according to God's word. As Bucer argued, it was not wise to reject out-of-hand the practices of the early church such as confession or fasting. ${ }^{18}$

By the end of the 1530s Bucer was advocating the introduction of the pre-communion examination in his own church in Strasbourg. The precommunion examination, with its opportunity for private confession, counsel, and instruction, was in Bucer's eyes an ideal vehicle for pastors to meet with their parishioners and to teach them the moral implications of their Christian faith. Together with the catechization of children it enabled the clergy to shape the moral values of their spiritual charges.

The second element of Bucer's plan of church discipline was a public profession of faith and obedience to the church and its ministers. For this purpose he recommended the introduction of an evangelical confirmation ceremony. Bucer first suggested the use of a confirmation ceremony in 1531 as a means of countering the Anabaptists' insistence on a public profession of faith. ${ }^{19}$ Scholars have often linked his proposal of an evangelical confirmation ceremony with Erasmus' suggestion, in his Paraphrase on Matthew, that children be instructed in the essentials of the faith and then confirmed. In his first catechism, written in 1534, Bucer himself cited as his model the practice of the early church in which

the bishops went from one place to another (within the area) which had been entrusted to their care, and from those who had been baptized as infants they received a confession of faith, instructed them further, laid their hands on them and anointed them as a sacrament of increase of the Holy Spirit and confirmation in Christian living. ${ }^{20}$

Bucer condemned the Catholic sacrament of confirmation as "a children's game contemptuous of God." He rejected the anointing with the chrism as superstitious and unnecessary, since it had not always been used by the church in the way the imposition of hands had been. ${ }^{21}$ To the imposition of hands, however, Bucer was willing to grant a quasi-sacramental character. It had not been expressly commanded by Christ, as had baptism and the Lord's Supper, but Christ had laid his hands on children, and the practice had been continued by the apostles and the early church. The imposition of hands was a symbol of God's acceptance and blessing, and it was therefore appropriate that it be practiced not only in confirming

18Ibid., no. 614 , p. 718.

19In his memorandum to Ambrosius Blarer before the conference at Memmingen, written Feb. 20, 1531, Schie $\beta 1$, no. 187, p. 245; cf. his suggestions of 1533-34 in Bericht au $\beta$ der heyligen geschrift, DS-5, p. 176; Quid de baptismate infantivm ivxta scripturas Dei sentiendum . . . (Strasbourg: [Mathias Apiarius], 1533), fol. $\mathrm{F}_{3} \mathrm{a}$; excerpt also printed in Manfred Krebs and Hans Georg Rott, ed., Quellen zur Geschichte der Täufer, Elsaß, Quellen und Forschungen zur Reformationsgeschichte (Gütersloh: Gerd Mohn, 1959-; hereafter TAE), vol. 2, no. 471, p. 224.

201534 Catechism, DS-6,3, p. 92.

${ }^{21 B e s t e n d i g e ~ V e r a n t w o r t u n g ~ a u ~} \beta$ der Heiligen Schrifft . . . (Bonn: Laurentius von der Mülen: 1545), 64r-65r. 
children but also in ordaining ministers and reconciling repentant sinners with the church.

The essence of the ceremony, however, was neither the anointing with oil nor the imposition of hands, but rather the public profession of faith and of obedience to the church made by the confirmands. Bucer stated the need for this public profession in his 1534 Catechism, but his emphasis on its importance was especially marked in his writings of the 1540 s. By making a public profession of faith and obedience, individual Christians signalled their submission to the disciplinary oversight of their pastors and the lay elders who assisted them.

The logical conclusion to which Bucer's emphasis on public profession of faith and obedience led him was the formation of the so-called "Christian fellowships" within the Strasbourg church during the last years before his forced exile from the city in early 1549. In a work describing the shortcomings of the Strasbourg church written in 1546 but never published, Bucer proposed that in each parish, those Christians who were willing would make a public profession of faith and obedience and have their names enrolled in a special register. Bucer later defended the requirement of a public profession of faith and obedience before enrollment in a parish fellowship by comparing such a profession to the public ceremonies which marked acceptance into civil organizations:

We see how, at the opening and beginning of all important activities and organizations which men want to be held in particular respect, they make use of festivities which include special vows and promises and all kinds of ceremonies. For instance, no one is allowed or accepted into a trade, guild, or citizenship in a city without such vows and various ceremonies; and these also serve to cause such activities and organizations to be of greater interest and more highly regarded among all honest people. ${ }^{22}$

Even more importantly, God required his people to confess their faith and their obedience to his law, as was abundantly clear from the example of the Israelites' covenant with God in the Old Testament and the numerous references to public professions of faith in the Psalms. ${ }^{23}$

Once enrolled in a fellowship, parishioners would be subject to the special oversight and discipline of the pastor and of lay elders who would be chosen from among this group. Eventually those who had enrolled in each parish group began to come together to hear an exhortation by the pastor, have an opportunity to be instructed on questions of doctrine, and to witness the admission of new members to the group. In essence, Bucer argued, these meetings were catechism classes for adults.

${ }^{22}$ Kurtzer Vnderricht vnd Grunde, DS-17, p. 263.

${ }^{23}$ Wegen Abschaffung grober Laster, DS-17, pp. 213-16. 
The chief purpose of the parish fellowships, however, was discipline. In memoranda he wrote defending their establishment, Bucer outlined the procedures for disciplining any of the members who had fallen into sin. Each member was responsible for admonishing any of his brethren whom he saw in sin, and the pastor and lay elders were particularly responsible for the oversight of each individual in the fellowship. Where individual admonition failed, the sinner was brought to the attention of the pastor and elders, who attempted to correct him through their admonition. Those who refused to heed the admonition were told to abstain from reception of the sacrament, excluded from the fellowship, and subjected to the ostracism of other fellowship members. Those who repented after such an exclusion or who were guilty of grave sin were bound to perform acts of penance for a period before they could be reconciled with the church in the presence of other members of the fellowship.

Previous studies of the "Christian fellowship" movement have generally assumed, on the basis of later developments in Strasbourg after the imposition of the Augsburg Interim and Bucer's exile, that the fellowships functioned as a sort of "church within a church" separating "true believers" from the mass of nominal Christians in the city church. This view makes the "fellowships" seem more separatistic than Bucer intended them to be. It would be more accurate to regard the members of the "fellowships" as adults who had been confirmed. Enrollment in the "fellowships" served the same function as a public confirmation ceremony, or as adult baptism had in the early church. Those who did not enroll in a "fellowship" were regarded as catechumens, a term which Bucer used on other occasions to describe the status of individuals present at a communion service who chose not to receive the sacrament. ${ }^{24}$

The "fellowships," with their public professions of faith and submission to the elders' authority, were not a completely new attempt to exercise discipline in the face of opposition to its introduction in the church at large by the city's magistrate, as some have suggested. ${ }^{25}$ Neither were they a temporary aberration from Bucer's convictions concerning the exercise of discipline in the church, to be abandoned when he moved on to a new field of ministry in England. In his Censura on the first Edwardian Prayer Book of 1549, Bucer recommended that "children who show in their life and conduct no signs yet or only modest signs of the faith and fear of God (should be) left among the catechumens" rather than accepted into full membership of the church through confirmation. The recitation from

${ }^{24} \mathrm{Cf}$. his letter to Simon Grynaeus and the other Basel pastors, March 7, 1532, Simler Sammlung, Msc S 31, fol. 63 pp., of the Zürich Zentralbibliothek, and the draft of the Strasbourg church ordinance of 1534 written by Bucer, printed in DS-5, 415-17.

${ }^{25} \mathrm{As}$, for instance, Walther Köhler, Zürcher Ehegericht und Genfer Konsistorium, vol. 2: Das Ehe- und Sittengericht in den Süddeutschen Reichstädten, dem Herzogtum Württemberg und in Genf, Quellen und Abhandlungen zur schweizerischen Reformationsgeschichte X, II. Series der Quellen zur Schweizerischen Reformationsgeschichte XIII (Leipzig: Heinsius, 1942), 470-71. 
memory of the words of the catechism was not an adequate confession of faith, and it made a mockery of the profession of obedience to Christ and his church. ${ }^{26}$ By distinguishing between "catechumens" and those granted "the full communion of Christ" in this way, Bucer was confident that "the lawful discipline and communion of Christ" could easily be restored to the church.

As mentioned above, the responsibilities of the members of the "Christian fellowships" included fraternal admonition. From his earliest discussions of church discipline on, Bucer stressed that the essence of discipline was not excommunication but admonition with the goal of the sinner's repentance. Admonitions to repent were not merely to be given once at each of the three stages prescribed in Matthew 18, the model for the exercise of discipline, but were to be repeated at each level for as long as there was hope that the sinner would listen. ${ }^{27}$ Excommunication, as the most drastic remedy for sin, was to be applied only when all else had failed. Bucer criticized the Anabaptists for their extreme eagerness to separate from all whom they regarded as sinners:

Separation is the final, and a dangerous remedy which we apply to our fallen brothers, and when we use it first, we are like doctors who apply medicines which are uncertain and full of danger at the beginning of an illness and like ships' captains who, as soon as a more brisk wind begins to blow, immediately think about casting their wares and provisions into the sea. ${ }^{28}$

Bucer's assertion of the priesthood of all believers meant that he viewed admonition as the responsibility of each and every Christian. However, in cases where an individual felt unable to admonish a sinner himself or where the sinner refused to listen to the admonition of his brother, the case was to be brought to the attention of the pastors and lay elders. Bucer often repeated that as those responsible for the care of souls, the pastors and elders had particular responsibility for the spiritual condition of their charges, and parishioners were to submit to their guidance and discipline.

It is generally recognized that Calvin developed his four offices of the ministry-pastors, teachers, elders and deacons - under Bucer's influence during his stay in Strasbourg between 1538 and 1542. Bucer was not quite so clear in his discussion of church office, for he differentiated only between the pastors and elders, who together were responsible for the spiritual well-being of their flock, and the deacons, who were responsible

${ }^{26}$ E.C. Whitaker, Martin Bucer and the Book of Common Prayer, Alcuin Club Collections 55 (Great Wakering: Mayhew-McCrimmon, 1974), 100-6.

27Bucer to Grynaeus and the Basel pastors, Mar. 7, 1532, Simler Sammlung Msc S 31.

${ }^{28}$ Enarratio in evangelion Iohannis, in Martini Buceri Opera Omnia, Series 2: Opera Latina (Paris/Leiden: Brill, 1955-; hereafter OL), 2:483. 
for the material well-being of the church's members. ${ }^{29}$ However, Bucer did share with Calvin a conviction that Scripture required the appointment of elders and deacons. His suggestion that the members of each "Christian fellowship" choose elders from among their midst to be responsible for oversight and discipline grew out of his frustration with the fact that the church wardens, appointed by the city magistrate for the task of moral supervision and considered the functional equivalent of elders in the Strasbourg church, were often negligent in performing their duties. ${ }^{30}$

The city's church ordinance of 1534 had given the church wardens the authority to meet regularly and to summon to appear before them individuals from their parishes who did not attend the sermons or receive the sacraments, or whose lives caused offense. This provision apparently remained a dead letter, because in January 1539 the Senate, at the urging of the pastors, resolved to see that it would be put into practice in the future. ${ }^{31}$ To this end a new mandate was drafted and published at the end of the month which repeated the provision from the 1534 ordinance and stated that those who disobeyed the summons or who refused to accept the admonition of the wardens were to be referred to the Senate, "which would take appropriate action towards them." 32 Thus the 1539 mandate on summoning gave the church wardens more leverage to carry out their responsibility of moral supervision and attempted to rectify a situation of which the pastors had long complained, the tendency of parishioners to ignore such summons when they were made.

The new mandate did no good, however, for most of the church wardens made no effort to exercise their authority. When the wardens from one parish did attempt to use their power to summon parishioners, they met with heated opposition, as is evident from the description of a stormy meeting of the Senate in June of 1541. The entire session was a continuation of an altercation which had arisen between the senators Claus Kniebis, an ardent supporter of the Reformation and a warden in Bucer's parish of St. Thomas, and Junker Jakob Wetzel von Marsilien, a Catholic who opposed the attempts of the church wardens to carry out their duties of oversight and admonition. ${ }^{33}$ When Kniebis brought the matter before the Senate,

${ }^{29}$ This is the division Bucer gives in Von der waren Seelsorge, DS-7, 114-21; cf. Gottfried Hammann, Entre la Secte et la Cité, Le Projet d'Église du Réformateur Martin Bucer, Histoire et Société 3 (Geneva: Labor et Fides, 1984), 276-82.

${ }^{30} \mathrm{Cf}$. his statement in Von der kirchen mengel vnnd fähl that these elders were to be chosen so that pastors had the help they needed when the church wardens could not or would not assist in the exercise of discipline, DS-17, 184.

31TAE 3, no. 889, pp. 307-308.

32Ibid., no. 890, pp. 308-9.

${ }^{33}$ Ratsprotokolle (RP) 1541, June 8, fols. 243v-248r, Archives Municipales of Strasbourg; summary in TAE 3, no. 1113, p. 475; biographical information on Kniebis and Wetzel von Marsilien in Thomas A. Brady, Jr., Ruling Class, Regime and Reformation at Strasbourg 1520-1555, Studies in Medieval and Reformation Thought 22 (Leiden: E.J. Brill, 1978), 326-27, 353-54. 
Wetzel von Marsilien insisted that it be discussed publicly, against the Senate's usual practice, and it was only after much shouting, which finally ended in Wetzel's being placed under house arrest, that Kniebis was able to present his side of the story.

Kniebis stated that the wardens of the parish of St. Thomas wished to carry out their responsibilities as set forth in the original ordinance of 1531 which had created their office, as well as in the church ordinance of 1534 and the mandate on summoning of 1539. Spurred on by "the many complaints of the pastors and their assistants, " they had determined to play a more active role in the oversight of their parishioners. To this end they had begun to summon groups of citizens to read them the mandates which were the basis of the wardens' authority, to forestall possible criticism or noncompliance with summons. On the previous Sunday, twenty-one men had been called to hear the warden's message. Wetzel von Marsilien also appeared, although uninvited.

When Kniebis began to read the ordinances to his audience, Wetzel "laughed scornfully out loud." Kniebis, taken aback, tried to dismiss the group to prevent further public disagreement, but Wetzel told them to remain, then turned to Kniebis and directly defied the authority of the wardens. He asserted that neither he as a senator nor anyone else need appear when summoned by the wardens. The magistrate alone was responsible for the city's inhabitants, and if and when it had anything to discuss with him, it would do the summoning. He rejected Kniebis' claim that the church wardens and the pastor's assistant were to be obeyed as ministers of the church and then proceeded to insult Jakob Bedrot, the assistant at St. Thomas. ${ }^{34}$ Wetzel's manner became more threatening, and according to Kniebis, a fight was only barely averted. Kniebis closed his presentation by stating piously that his intent was not to accuse Wetzel but to obtain the Senate's backing for their mandates and for the efforts of the church wardens. After much discussion, the Senate decided to allow the wardens from St. Thomas to continue with their efforts and to tell the other wardens to follow their example, so that practice would be the same in all of the parishes.

The incident reflects both the apathy regarding their duties of moral oversight on the part of all but the most zealous of the church wardens and

Brady's surmise that the latter may have been Catholic is strengthened by the statement in the Ratsprotokolle that when he took an oath with the phrase, "with the help of God," Wetzel added "and the pious saints," RP 1541, fols. 246r-246v; he also accused Jakob Bedrot, who was the first person appointed to the chapter of St. Thomas by the magistrate in defiance of the papal right of provision, of wrongful possession of his benefice, ibid., fol. 247v; cf. Gustav Knod, Die Stiftsherren von St. Thomas zu Straßburg (1518-1548), Ein Beitrag zur Kirchen- und Schulgeschichte, Beilage zum Programm des Lyceums zu Straßburg (Strasbourg: C.F. Schmidt, 1892), 4-5. Lorna Jane Abray notes that Wetzel was fascinated by the Anabaptists, but that his family was Catholic, The People's Reformation: Magistrates, Clergy and Commons in Strasbourg, 1500-1598 (Ithaca: Cornell University Press, 1985), 176.

${ }^{34}$ Bucer, the pastor, was at the time in Regensburg for the religious colloquy and Diet. 
the hostility faced by those few who did try to carry out those duties. Given the wardens' lack of effectiveness, it is not surprising that Bucer would suggest that the parish fellowships choose their own lay elders and insist that the members of the fellowship submit to their oversight.

Finally, let us turn to that which is generally considered as discipline proper: the use of public penance and excommunication. Bucer was not alone in his insistence on the imposition of public penance; Johannes Oecolampadius of Basel had also advocated its use according to the model of the early church. Bucer originally had doubts about the effectiveness of reintroducing the practices of the early church. As he wrote to Zwingli in 1530, he feared that Oecolampadius "favored too much the severity of the Fathers, by which more harm than good was often brought into the church." 35 He soon changed his mind, however, and in his later writings on the question of church discipline he never failed to include a strong defense of the use of public penance.

Bucer derived the minister's right to impose a period of public penance on grave sinners from the power to bind and loose sin given to the church by Christ. He also used examples from the Old Testament histories, the New Testament Epistles, and the writings of the church fathers to argue that the imposition of penance was both necessary and commanded by God. ${ }^{36}$

Public penance differed from the satisfaction imposed by a priest in the sacrament of confession in that it was meant to satisfy the church of the sinner's repentance, not to satisfy God for sins committed. Bucer insisted that when a person had injured the church by grave sin that was public knowledge, it was not sufficient for that person to claim that he was sorry for his offenses; he had also to demonstrate that repentance by performing acts of penance such as fasting, prayer, self-denial, diligent attendance at worship services, and almsgiving. The penance performed by the sinner had the added advantage of serving as a deterrent to sin for the rest of the congregation.

To support this position, Bucer compared the imposition of penance to the actions taken by a ruler towards a rebellious subject:

Where the subject of a lord has gravely sinned against his lord and thereby forfeited his life, and the lord is persuaded to forgive him on the basis of his promise of amendment, will he not also desire him to prove by some kind of penance his contrition and amendment to the other citizens as a good example, so that others will be deterred from such misdeeds and disobedience? Such a lord will command his officials, "You should forgive and spare the lives of all those who are sorry for their disobedience and desire to reform, but as an example to the others you should discipline them so that one can see that they are truly sorry for their sin and misdeeds." Must not this official, if he

35Z Xl, no. 1118, p. 199.

${ }^{36}$ Von der waren Seelsorge, DS-7, 161-68. 
wishes to be truly obedient to his lord, still impose some form of penance on these people, whom he forgives on account of his lord, and diligently observe them to see how sincerely they devote themselves to amendment?37

When the sinner refused to heed admonition and repent, then the final step of excommunication was taken. This was more than simple exclusion from the Lord's Supper; it meant elimination from the total life of the church. Those who were excommunicated and remained contumacious could not stand as godparents at a baptism or act as witnesses at a wedding ceremony, were not given pastoral consolation when sick, and were denied a church burial if they died before being reconciled with the church. ${ }^{38}$

Excommunication also entailed social ostracism: other Christians were to avoid all unnecessary contact with the sinner, although they were to fulfill all civic or familial obligations due him. Bucer used an illustration from civil life to demonstrate how excommunicates were to be treated by the rest of the church:

Respectable people . . . have dealings with those they otherwise avoid in the things which civil society or common human necessity require, and they do with them what has been imposed on them all by the magistrate. So, for example, they eat with them and do other things, work, buy and sell, and help them in need. But beyond this they do not accept them, have nothing to do with them, avoid their company and in all things demonstrate their aversion and indignation at their wanton and dishonorable life. Christians should act in the same way towards those who have been excluded from God's church. ${ }^{39}$

There were two important exceptions to the rules of exclusion from all church ceremonies and of ostracism by the church community. Excommunicates were always to be allowed to hear sermons, since they might thus be brought to repentance, and other Christians were to take every opportunity to admonish the sinner to repent. If and when repentance did result, the sinner was then subjected to public penance, and when he had satisfied the church of his sincerity, he was to be publicly reconciled to the church by the pastor.

Protestant historians have often maintained that the reformers rejected major excommunication with its civil penalties and wished only to exclude excommunicated sinners from the Lord's Supper. It is clear from Bucer's writings, however, that he understood the ban to be major, not minor excommunication. Even with regard to the civil consequences of excom-

37lbid., 171, 181-83; quote 182-83.

385ee the provisions concerning excommunication in the Ziegenhain disciplinary ordinance, DS-7, 267-71, and the Cologne church ordinance, Hermann von Wied, Einfültiges Bedenken: Reformationsentwurf für das Erzstift Köln von 1543, ed. and trans. Helmut Gerhards and Wilfried Borth (Düsseldorf: Presseverband der evangelischen Kirchen im Rheinland, 1972), 169-71. 
munication Bucer endorsed the medieval practice. He believed that it was the responsibility of the magistrate to impose civil punishment for sin, and he expected the governing authority to act against contumacious sinners:

Where there is a proper, God-fearing government, the imperial statutes and old Christian practices towards those banned from the church will be enforced also in their civil relationships, as they have deserved, and through civil exclusion and avoidance which the magistrate brings about they will be brought to reformation. For heathens among Christians should be held as heathens. ${ }^{40}$

Excommunication was not a civil punishment per se, but in Bucer's eyes it should have civil consequences imposed by the magistrate after the church has pronounced its sentence.

In all four elements of discipline Bucer's purpose was the amendment of the sinner, the progress in piety of the individual Christian, and the edification of the church. In his discussions of discipline, the word which occurs most frequently is Besserung, best translated as amendment or reform. Excommunication of the contumacious was done in part to prevent the contamination of the rest of the church by false doctrine or wrongful behavior and to serve as an example to others, but it was also intended to provoke shame and repentance in the sinner. ${ }^{41}$ Any penance which was imposed was to be tailored to the individual sinner and the specific circumstances of $\sin$ so that it would better promote true repentance. ${ }^{42}$ Likewise individual Christians were to admonish their brethren in a spirit of love and for as long as there was hope that the sinner would listen; sin was not to be reported to the pastors and elders unless such admonition had failed. ${ }^{43}$ Religious instruction, whether in catechism classes or services or as a part of private confession, was to deepen the individual's understanding of his sinfulness, increase his thankfulness and faith in God, and encourage him in service to his neighbor. The public profession of faith and obedience placed him firmly under the pastoral authority of the ministers and lay elders, who used instruction, counsel and discipline to instill proper doctrine and behavior and to correct lapses in faith or morals.

Bucer's broad definition of church discipline reflects his concern that belief should influence behavior. It was the pastor's responsibility to see that his charges understood the essentials of their faith and reflected the consequences of that faith in their actions. Private confession was especially useful for this purpose, for it allowed the pastor to examine his parishioners' knowledge of the catechism, to instruct them where necessary, and to guide their conduct by shaping their conceptions of right and wrong. But all the elements of church discipline were intended to aid the internalization of

40Ibid., 222.

41 Ibid., 219-21.

42Ibid., 176-80.

431534 Catechism, DS-6,3, 87. 
moral norms and thus provide a standard for the individual Christian's behavior. In this respect, Bucer's ideas foreshadow some of the techniques used in the second half of the sixteenth century by Lutherans, Calvinists, and Catholics alike to shape the confessional identity of their members. ${ }^{44}$

Bucer's emphasis on moral reformation and progress in piety as the goal of church discipline reflects the influence of Erasmus. The Strasbourg reformer was an ardent disciple of Erasmus when he first heard Luther's evangelical teachings, and throughout his life he retained an Erasmian concern for inner piety and outward acts consistent with Christian faith and love. Bucer drew his conviction of the pedagogical value of private confession from Erasmus, and he may have derived his first ideas on the development of a public confirmation ceremony from the Dutch humanist as well.

Although Bucer rejected many of the institutions and practices used by the Catholic church for the purposes of religious instruction and the control of morals, he retained some elements of the Catholic system in devising his own structures for these purposes, particularly in those cases, such as public penance, where he could justify their use on the basis of scripture or the writings of the church fathers. Bucer was not so innovative in his approach to discipline that he could devise an entirely original system, and his great respect for patristic authority made him more inclined to make use of those pastoral and disciplinary structures which had existed in the early church. As he stated in the preface to the third edition of his commentary on the Gospels, "Nothing that is proposed in the name of God should be rejected, even if proposed recently by some individual; how much less should that be repudiated rashly which holy antiquity and the public consensus of believers through so many centuries commends to us." Bucer saw a prime example of this kind of rashness in the rejection of "what [believers through the centuries] have handed on to us in the name of Christ . . . before we have actually examined it and are convinced that is has nothing from the Spirit of Christ." 45 Given this attitude, it is not surprising that he drew as much as he could, within the limits of his evangelical beliefs, from the institutions and practices of the early church.

Bucer often condemned medieval disciplinary practices as perversions of what had been established in the early church. The bishops of the early medieval church had lost their vigilance and fervor in carrying out their spiritual responsibilities and had become preoccupied with secular con-

${ }^{44}$ See the discussion of methods of confessionalization in the articles by Wolfgang Reinhard, "Konfession und Konfessionalisierung in Europa," in Bekenntnis und Geschichte. Die Confessio Augustana im historischen Zusammenhang, Ringvorlesung der Universität Augsburg im Jubiläumsjahr 1980, ed. Wolfgang Reinhard (Munich: Vögel, 1981), 165-89, and "Zwang zur Konfessionalisierung? Prolegomena zu einer Theorie des konfessionellen Zeitalters," Zeitschrift für historische Forschung 10 no. 3 (1983):257-77.

${ }^{45}$ In sacra quatvor evangelia, Enarrationes perpetvae, secundvm recognitae, in quibus praeterea habes syncerioris Theologiae locos communes . . . (Basel: Herwagen, 1536), fol. *2v. 
cerns. Consequently they had found it easier to establish fixed penalties for specified sins than to apply penance according to each individual's needs. The commutation of these penances for a fee had then led to the development of indulgences. The voluntary confession of sins which troubled the conscience, as recommended by the church fathers, had been twisted by the pope's requirement that everyone, whether penitent or not, must make a yearly confession. Excommunication, necessary to protect the church from contamination and to produce shame and repentance in a sinner who otherwise would not heed admonition, had been turned into a method of extorting payment of debts and tithes. As a result, the people were unwilling to allow the evangelical pastors to use it, fearing the creation of "a new papacy." But, as Bucer argued, fear of a thing's misuse was no justification for its disuse. Preaching, the administration of the sacraments, even the office of the magistrate had all been misused, "but do we therefore want to have no preaching, sacraments or magistrate? What God has commanded must be good and bring about only good, and we should establish those things and observe them according to God's word for as long as we can." 46

The failure to establish the structures of discipline which Bucer believed were commanded by God's word left him extremely pessimistic about the fate of the evangelical church in Germany. He interpreted the defeat of the Schmalkaldic League as divine chastisement for the evangelical church's lack of repentance and its rejection of discipline. ${ }^{47}$ In an open letter to the Protestants in Bonn written in 1547, Bucer described how God punished the nation of Israel for its disobedience, maintaining that "we socalled Christians have long deserved even more severe punishment and disciplining than we have already experienced." 48 Although the Protestants had rejected the abuses which had crept into the church over the last five or six hundred years, they had not established their congregations "according to the true apostolic order and the example of the first churches, "with the proper exercise of fraternal admonition, the binding to penance and the excommunication of those who sinned and would not repent. 49

${ }^{46}$ Mehrung götlicher Gnaden vnd Geists, DS-17, 336.

${ }^{47}$ See, for example, his letters to the Landgraf on March 25, 1547, Lenz II, no. 249, p. 489 , and to Ambrosius Blarer on May 13, 1547, Schie $\beta$ II, no. 1438, p. 623. In response to Oswald Myconius' statement that his view of the situation was too gloomy, Bucer responded, "Nuntiavi tibi subinde, quas nobis Dominus plagas inflixit, et id fere infra, non supra verum. Tua laeta rejeci, quia falsa sciebam. Questus hinc sum de peccatis nostris et ira Dei, quam nostra impietate accendimus. Metuere me graviora testatus sum, nisi poenitentia vera Dominum placeremus." February 1, 1547, TB XVIII, fol. 13r.

${ }^{48}$ Das sich niemand zu verwunderen habe . . . ab der schweren triebsal diser zeit, DS-17, 86109; the citation is the title of the main body of the letter, p. 88.

${ }^{49}$ Ibid., 100-1; the period of 500-600 years, pp. 95-96. 
This same pessimism and sense of impending doom led Bucer to make his strident demands for the introduction of discipline in his lectures and sermons at Cambridge. The optimism with which he had foreseen the transformation of society when the evangelical Gospel was first announced had turned to bitter disappointment at the laity's lack of interest in such transformation. His prescriptions for a system of discipline within the evangelical church had not been tried and found wanting, but were unwanted and left untried. 